\title{
ATTITUDE-BEHAVIOUR GAP AMONG POLISH CONSUMERS REGARDING GREEN PURCHASES
}

\section{Lucyna Witek}

Rzeszow University of Technology, Rzeszow, Poland

The purchasing behaviour in the market of green products is at a low level. Consumers express their concern about the future of the planet and the cleanliness of the environment, but in their conduct they do not take into account ecological criteria. There is a discrepancy between what consumers say and what they really do. A favourable attitude to the idea of environmental protection does not translate into real action. The reasons for this gap have not been sufficiently researched yet. The aim of the research is to identify the causes of attitude-behaviour gap in the market of environmentally friendly products in Poland. To achieve the goal, the desk research and surveys were applied. The research shows that green products are well evaluated by consumers, although the knowledge about them is general and partial. Only $21 \%$ of respondents indicate knowledge of the production process, certification and control of environmentally friendly products. A large group of surveyed consumers (43\%) shows willingness to pay higher prices for environmentally friendly products. But only one third of respondents (32\%) declares trust in such products.

Keywords: attitude-behaviour inconsistency, ecolabels, environmentally friendly products, green consumer, green marketing

\section{Introduction}

The concept of sustainable development has made fundamental reassessments in the thinking and actions that take into account the issues related to the environment and its protection. The processes of globalization, the growth of social inequality, and industrialization economies caused the realization of the negative impact of socio-economic development on modern civilization. One of the major problems is the threat to the whole world, the natural environment and its individual components due to the reasons related to over-exploitation of natural resources, inappropriate production technologies and increasing consumption. Discussions on these issues were taken in the seventies in the Report to the Club of Rome. Particularly large contribution to the development of this concept had the Brundtland Commission in 1983, which set the objective of sustainable development as meeting the needs of the present without compromising the ability to meet the needs of future generations. An important event for the implementation of sustainable development was the summit in Rio de Janeiro in 1992, where Agenda 21 was passed, which included a program of action for the protection of the environment especially moving problems with the rational management of natural resources to achieve sustainable development. This had an impact on the development of scientific research which was related to the elaboration of new concepts and models of economic development.

The article focused on the issue of the behaviour of purchasers in the market for green products. In Poland, the subject has been poorly recognized so far. Most of the research related to consumer behaviour in the market for green products focuses on organic food and a large group of studies analysing the state of the environmental awareness of Polish society. These issues are extensively discussed in English literature, but in the Polish market the process of shaping environmental purchasing behaviour is different than in the market of highly developed countries. The consumers have different characteristics and their behaviour is affected by economic, cultural, historical, and many other factors.

The research indicates a clear incoherence between attitudes and real behaviour towards green products which is referred to as green purchasing inconsistency, or values-action gap. The reasons for this gap in behaviour have not been sufficiently researched yet. There are significant studies on ecological awareness and determinants of ecological behaviour of consumers. However, the recognition of factors affecting the green purchasing inconsistency of consumers remains limited.

This study attempts to identify the causes of this inconsistency and suggests some steps to address these issues to encourage consumers to buy environmentally friendly products. The study is a valuable contribution to research and a discussion on consumer behaviour in the market for green products. It presents a comprehensive approach to the green purchasing inconsistency. Producers give tips on how to create green marketing strategies. It can help other groups of stakeholders, for instance, politicians, ecological movements in solving ecological problems and improving the quality of life of present and future generations. The existing barriers to the purchase of green products may lead to the abandonment of green products, which makes it difficult for companies to implement eco-friendly marketing strategies.

The green market is a currently fast-growing market sector in developed countries. In 2008 in the eco-sector of the employed in the EU was around 3.4 million employees, turnover of the sector amounted to over 300 billion, and its growth was 7-8\% per year (European Commission, 2009). Organic food is a basic segment of the market for green products. The organic food market is currently one of the most dynamically developing sectors of the food industry, but it is still small. It is estimated that global market for organic food reached in 2010 - 59 billion USD (in 2008 - 51 billion USD, in 2006 - 38.6 billion, in $2004-28$ billion USD). Europe has the largest and the most complex market for organic food. Sales are concentrated in Western Europe, especially in Germany and the UK, where it recorded its fastest growth on the continent. In Europe, sales of organic products reached 17.9 billion in 2010 (Orboi et al., 2012). The biggest sales generate Germany, where its value is estimated at 5.9 billion EUR (there was a $2 \%$ increase) compared with the previous year. In France it reached 3.4 billion EUR (up by 10.8\%), and in Italy -2.8 billion EUR, with an increase of $12 \%$ (Willer, 2012). Countries such as Germany, the United Kingdom, France and Italy account for over $75 \%$ of European revenues, while Denmark, Sweden and the Netherlands have a high demand, although their markets are much smaller due to the small number of consumers. The largest number of organic producers is in Italy (46 thousand), 
Spain ( 30 thousand) and in Poland (26 thousand). Consumer spending in the EU on organic food in 2013 amounted to $€ 22$ billion, which increased by almost $6 \%$ compared to the previous year. The highest sales were generated in France ( $€ 4.4$ billion), the UK ( $€ 2.1$ billion) and Italy ( $€ 2$ billion). Spending on organic food per 1 inhabitant in 2013 was the highest in Denmark (€ 164), Luxembourg (€ 157), Austria (€ 127 in 2011), Sweden ( $€$ 107) and Germany (€ 93). However, one needs to be careful in interpreting these data because of the different standard of living in different countries (European Parliament, 2015).

Not only the interest of consumers, but also the agricultural policy and state aid and the inclusion of large stores to sell organic products affect the growth of this market. Hartman Group (2008) gives other factors that contribute to the intensive development of the market for organic products, namely:

$\square$ increased debate of government, industry and non-governmental organizations on the definition of "organic", "green";

$\square$ growing concerns about the potential health risks particularly associated with antibiotics and hormones in meat and dairy products;

$\square$ access to food through specialized organic shops and supermarkets;

$\square$ increased availability of organic products through lower prices resulting from lower costs;

$\square$ combining the brand image of health and ecology;

$\square$ the belief that organic products are safe and "healthy".

In the case of organic food, there are precise data on its supply. One can also find data on the volume of sales of food, as well as a clearly defined legal framework labelling of organic food, allowing to clearly distinguishing organic from non-organic food. In the case of other green products than organic food there are no specific data on the supply and selling them. A large number of characters, the lack of a uniform system of eco-labelling of products mean that consumers are confused and distrustful (Terenggana et al., 2013). They have difficulty determining whether a product is environmentally friendly.

In the scientific literature there is a debate about social values and their impact on consumer decision-making (Carrington et al., 2010; Hosta and Žabkar, 2016). One may notice a growing interest in socially responsible consumers (Follows and Jobber, 2000). Especially in times of ecological crisis the discourse on issues of consumer attitudes and behaviour towards the environment and their impact on purchasing decisions becomes meaningful (Zanna and Fazio, 1982; Kaiser and Wolfing, 1999; Haws et al., 2014). The market for environmentally friendly products is growing dynamically in the world, but the share of green products in the market is still small. Green behaviour in the Polish market is underdeveloped. The number of consumers regularly purchasing green products is small. Despite the positive connotations of environmental protection and green products the consumers are not their purchasers (Bartels and Hoogendam, 2011). Consumers express their concern about the future of the planet and the cleanliness of the environment, but this does not necessarily mean a green purchase (Fura, 2017; Young et al., 2010; Hughner et al., 2007).

There is a discrepancy between what consumers say and express themselves through their values and attitudes and what they actually do (Bray et al., 2011). A favourable attitude to the idea of environmental protection does not translate into real action. This discrepancy is referred to in the literature as a green attitude-behaviour gap. Positive attitudes towards environmental protection are not reflected in their purchases. The existence of green purchasing inconsistency is confirmed by numerous studies, e.g. Follows and Jobber (2000), Gupta and Ogden (2006). The pro-environmental attitudes are in line with accepted social norms, but in reality they are not reflected in individual consumer behaviour (Carrington, Neville, Whitwell 2010). These are the factors that can lead to discrepancies between consumer attitudes and consumer behaviour.

The attention was paid to other factors than distrust and high product prices that prevent the purchase of green products despite a positive attitude towards them (Gleim et al., 2012). These include a low level of knowledge about what a green product is and how to identify it in the market. Information asymmetries are important factors hindering the purchase of green products. There is also a lack of faith in consumers about the way they are produced in accordance with the principles of respect for the environment (Kollmuss and Agyeman 2002). Ecological attribute is perceived by consumers as the "healthy, safe" attribute. In addition, the low efficiency of marketing activities of green products results in their poor visibility and availability, which causes consumers to miss these products when shopping (Witek, 2017).

\section{Material and methods}

The aim of the research was to identify the causes of attitude-behaviour gap in the market of environmentally friendly products in Poland. To achieve the goal, the desk research and surveys were applied. The survey was conducted from December 1, 2015 to January 31, 2016 using the direct questionnaire method among 390 adult consumers in south-eastern and southern Poland (Table 1). The selection of the sample was non-random.

Table 1 The characteristic of sample

\begin{tabular}{l|c|}
\hline $\begin{array}{l}\text { Demographics } \\
\text { Gender }\end{array}$ & $\begin{array}{c}\text { Percent (N:390) } \\
\text { Female: 56; Male: } 44\end{array}$ \\
\hline Age & $\begin{array}{c}\text { Village:57; Town below 200 thousand inhabitants: 24; City above } 200 \\
\text { thousand inhabitants: } 19\end{array}$ \\
\hline $\begin{array}{r}\text { Place of living } \\
\text { Financial } \\
\text { situation }\end{array}$ & Bad: 8; Average: 33; Good: 45; Very good: 14 \\
\hline Education & Primary: 3; Vocational: 26; Secondary: 34; Higher:37
\end{tabular}

Source: own research

The 5-point Likert scale was used. The research was carried out at the significance level of $\alpha=0.05$. The following hypotheses were put forward:

H1: Consumers have a positive reception of environmentally friendly products.

H2: Knowledge of ecological marks, production methods, control and certification of green products and their purchase places is low.

H3: High prices are a barrier to buying environmentally friendly products.

H4: The main reason for abandoning environmentally friendly purchases of products is lack of confidence and scepticism about the environmental activities of producers.

\section{Results and discussion}

The research shows that consumers intuitively associate the green product more with health than with environmental protection. Over half of the respondents (60\%) consider certified eco-friendly products as higher quality. Only a small group of respondents (32\%) consider the impact of the product on the environment when shopping. Environmentally friendly products are perceived as products of higher quality, good for health, although at 
high prices. Regular purchases of green products are declared by $24 \%$ of respondents. Young et al. (2010) estimate that $30 \%$ of consumers are concerned about the environment, but only $5 \%$ of them are concerned about real behaviour. Even consumers with the highest level of environmental awareness do not always buy green products. Their selection of products depends on both environmental awareness and the assessment of various product characteristics and situational factors (Rokka and Uusitalo 2008). Gutkowska (2007) indicates a conflict between recognized values understood as values of an objective nature imposed by social norms and everyday values understood as innate personal inclinations of the human individual. Consumers are looking for products that best meet their needs, and the imperative of responsibility requires them to give up their own benefits and buy environmentally friendly products. If the purchase of an eco-friendly product is associated with a change of habits, lack of comfort, incurring higher costs and dedication of additional time or acceptance of lower quality, consumers will be willing to avoid it. Otherwise, they would have to give up personal good for higher values. Consumers attach more importance to aspects that are of direct relevance to them than to lofty aims.

Purchase intentions are a strong predictor of purchasing behaviour towards green products, but stronger in mature markets than in emerging eco-markets (Thøgersen, 2009). Śliwak (2001) points to a higher level of the need for social approval by altruists. The idea of ecological consumption is becoming more and more common and has such a positive reception that it is not proper not to express its approval and probably that is why the majority of respondents support it and give correct answers (Lewicka-Strzałecka, 2015). An approval for commonly appreciated items and values allows consumers to maintain a positive image of themselves in both their and other people's eyes (Lewicka-Strzałecka, 2015).

On the one hand, the respondents consider themselves well informed about the labelling of green products (42\%). They have requirements for labels and information placed on them. One third of consumers (31\%) declares that they are carefully familiar with the labels. However, a group of consumers (29\%) complains that the information on the labels is unclear and incomprehensible. On the other hand, the research indicates the confusion of consumers under the influence of excess information about environmental problems (54\%) and general knowledge of the specificity of green products, labelling, control and certification. Only $21 \%$ of respondents have knowledge about the production, control and certification of environmentally friendly products. They think that other people do not know eco-labels very well $(57 \%$ - "rather yes", 12\% - "yes"). Knowledge of EU eco-labels (e.g. Euro Leaf or Euro Flower) is declared by $44 \%$ of respondents, and the national eco-label by the Polish Center for Testing and Certification) - 21\% respondents (Table 2). Knowledge about the environment and knowledge about green products has a positive relationship with the purchase of environmentally friendly products (Kumar, 2012).

The asymmetry of information between suppliers and recipients of green products is increasing since they are the goods whose quality consumers are unable to check before or during their consumption and must entrust the manufacturer with their properties or quality (Nestorowicz, 2017). In the Fietkau model, knowledge does not directly affect behaviour, but acts as a modification of attitudes and values (Kollmuss and Agyeman, 2002). Consumers feel insufficiently informed about the environmental and social aspects of green products. On the other hand, they feel overwhelmed by the amount of environmental information, sometimes contradictory one. Knowledge in the field of environmental protection and concerns about greenwashing are currently the factors that seriously hinder the process of purchasing environmentally friendly products (Braga Junior et al., 2014).
The most common explanations of green purchasing inconsistency in literature are a lack of trust and higher prices of environmentally friendly products (Barber et al., 2014; Steg et al., 2014). A large group of respondents believe that manufacturers use ecological signs for sales and image purposes (61\%). Only one third (32\%) has confidence in certified environmentally friendly products (Table 2). This is closely related to knowledge and responsibility and belief in the ability of a green product to meet needs. Confidence significantly affects shopping intentions (Chen and Chang, 2012). A significant share in weakening the trust in the green offer is instrumentally used by companies that want to improve their image (Pabian, 2014; Witek, 2016). It is becoming more and more common that companies compete in terms of information provided, and not the actual environmental performance behind it. Ecolabels are an important indication when shopping, guaranteeing the credibility of an environmentally friendly product, but in the Polish market it does not work at a satisfactory level. Almost half of the respondents (48\%) pay attention to the eco-labelling of products when buying, but only a small group precisely identifies them. A large group of respondents (51\%) is in doubt as to whether the label certainly guarantees pro-environmental product features. The number of eco-labels has increased, and the differences between labelling schemes and systems have led to a lack of clarity between various eco-labels (Harbaugh et al., 2011). The studies by Eden et al. (2008) show that consumers do not trust independent guarantee systems at all and suggest that consumer labelling gives consumers information about a product, but does not necessarily lead to a higher level of trust and a purchase. Consumers, on the one hand, are not fully aware of the certification and control process, which has the effect of raising their concerns about the authenticity of the green product, but on the other hand, they have some confidence in the organization i.e. they are willing to pay a higher price for their labelled products (Gerrard and Janssen, 2013). Consumer confidence is one of the most important factors in the success of the third-party certification program (Janssen and Hamm, 2012).

Since the subjects are not able to recognize the basic eco-labels, it can be assumed that they do not take them or take them into account, but to a much lesser extent than the product's environmental impact has been declared. The results of the survey indicate the important role of eco-labelling in communicating the benefits and attributes of green products through unified, reliable and simplified eco-labelling systems.

A large group of respondents $(77 \%)$ declared purchases of environmentally friendly products without eco-labels, but from a trusted source. This suggests that consumers express a need for high quality products with a positive impact on the environment and health (especially health motivation is strong in the Polish market), but do not buy certified green products due to higher prices, poor availability and distrust to environmentally friendly products (Witek, 2017).

Consumers are willing to pay a higher price for eco-labels products (Moon et al., 2002). Polish consumers are eager to pay a premium, but a small one. A consumer who will see benefits and has confidence in green products will be willing to pay a higher price. For Polish consumers, the price of a product is an important factor in the purchase. As much as $78 \%$ of consumers declare that they pay attention to it during shopping. Ecological products are seen as not only better quality, but also more expensive. On the one hand, more than one fifth of respondents (24\%) indicate that the products are for the rich. On the other hand, almost a half of the respondents (43\%) declares a high propensity to pay higher prices for certified green products. Higher prices of environmentally friendly products constitute a serious purchase barrier (Buder et al., 2014; Gleim and Lawson, 2014). The willingness to pay (WTP) 
Table 2 Consumer's attitudes and behaviour to green products (\%)

\begin{tabular}{|c|c|c|c|c|c|}
\hline Responses & Strongly agree & Agree & Neither nor/not answer & Disagree & Strongly disagree \\
\hline Products marked as eco-label are healthier for me and my family & 23 & 51 & 13 & 10 & 3 \\
\hline Environmentally friendly products are of higher quality & 25 & 36 & 20 & 10 & 9 \\
\hline When buying a product I consider the impact on the environment & 8 & 24 & 26 & 28 & 14 \\
\hline I regularly buy green products & 11 & 13 & 44 & 16 & 16 \\
\hline I read the labels carefully & 5 & 26 & 48 & 15 & 6 \\
\hline I am lost in the infoglut about environment and its problems & 11 & 43 & 35 & 8 & 3 \\
\hline I know how green products is produced and controlled & 10 & 11 & 53 & 17 & 9 \\
\hline $\begin{array}{l}\text { If I do not have the knowledge about the green product I'm inclined to choose } \\
\text { a product with an eco-label }\end{array}$ & 12 & 38 & 24 & 16 & 10 \\
\hline $\begin{array}{l}\text { I know the EU ecological signs - European Flower (green products) or Euro } \\
\text { Leaf (organic food) }\end{array}$ & 18 & 26 & 21 & 17 & 18 \\
\hline $\begin{array}{l}\text { I know the ecological mark given by the Polish Center for Testing and } \\
\text { Certification }\end{array}$ & 9 & 12 & 47 & 22 & 10 \\
\hline When I buy I return to the eco-label & 12 & 36 & 30 & 16 & 6 \\
\hline I have trust in certified green products & 14 & 18 & 45 & 17 & 6 \\
\hline Price is an important factor when choosing a product & 29 & 49 & 8 & 11 & 3 \\
\hline Environmentally friendly products are only for the rich & 12 & 12 & 21 & 43 & 12 \\
\hline I'm ready to pay a higher price for an eco-labelled product & 18 & 25 & 23 & 27 & 7 \\
\hline
\end{tabular}

Source: own research

is the key factor for the decision to buy environmentally friendly products (Moser, 2015).

The poor knowledge about the green products, their labelling, certification and control causes a lack of trust and scepticism towards green claims. This results in the lack of acceptance of higher prices for green products. In addition, insufficient marketing causes invisibility of environmentally friendly products. Taking into account the short-term perspective, increasing trust should be based on growing knowledge about products and their potential benefits, their method of production, control, certification and labelling. The perceived value of an environmentally friendly product (and not the price), and hence willingness to pay for green products is an important predictor of purchases (Moser 2016). In addition, effective communication is the key to build trust with consumers (Kuźniar and Witek, 2016).

Green products can be sold at reduced prices, but temporarily to trigger an incentive to try these products (Bezawada and Pauwels, 2013). Low prices do not take into account both higher production costs and marketing. In the Polish market, the price barrier is created at the retail level, where prices are raised by up to $100-400 \%$, using fashion for health and ecology. Green products also serve to emphasize the social status and to distinguish themselves in the group socially.

Another reason for the green purchasing inconsistency is the limited availability of environmentally friendly products and their poor visibility and other shortcomings in marketing, e.g. promotion (Buder et al., 2014). Green products in the Polish market are more and more visible on shelves and are increasingly available, but this is still not sufficient. The problems are errors in merchandising, e.g. joint display of organic products with functional food and food produced by traditional methods and products for vegetarians (so-called "healthy food"). This sales trick can mislead consumers, especially those not too familiar with the characteristics of the green product. Access to specialized stores requires additional effort, which will avoid convenience-oriented shopping by consumers.

In the case of products of frequent purchase, consumer decisions are automatic because they are based on habits or previous experience, based on low commitment and a tendency to avoid cognitive activities. However, in the case of green products, there is a need for cognitive effort to buy products based on ethical values (Young et al., 2010). An important step is raising consumer awareness and encouraging an increase of personal responsibility of individual consumers through education, social campaigns, marketing and promotion. In addition, for occasional buyers of green products, motivation may be additional hedonic benefits (taste, smell) and then sensory marketing may be an important instrument to encourage further green purchases. However, it should be noted that the main condition to overcome the gap is to build trust in certified green products.

\section{Conclusions}

The reason for this poor taking advantage of the market potential is not only low environmental awareness of Polish consumers, but also high prices, low level of marketing, low availability of green products and a lack of confidence in certified green products. Under these conditions, the need for the study of consumer behaviour in order to improve the processes of managing supply and demand of green products increases. Consumers intuitively combine environmental pollution with the threat of their own health. This type of consciousness is the most common one. Ecological values are seen as important if the threat directly affects the consumer, hence the importance of health theme when buying green products. One of the barriers to the development of purchasing behaviour in the market for green products is high prices of green products together with low-income consumers. 
Based on the analysis of available reports and test results it can be concluded that there has been an increase in the social, environmental and health awareness and the standard of living of Polish consumers, which gives the explication of the development of this market. Polish green products consumers perceive this as a specific group of food products with primarily pro-health values. Green products have become a symbol of better quality. This is connected with motives of the purchase, which is dominated by concern for the health. In comparison with other countries they are characterized by relatively low percentage of indications of environmental concern and support of organic producers. Growing concerns about the potential health risks, particularly associated with antibiotics and hormones in meat and dairy products, civilization diseases (cancer, diabetes, allergies) and increased debate among the government, industry and nongovernmental organizations, scandals food and publicizing in the media cause the exposition of health problems. Under these conditions, consumers are interested in striving to maintain health and safety.

From the point of view of the benefits for the environment and the health of the consumer, green products are widely accepted, but in economic terms they are usually accepted by consumers with higher incomes. Also, one needs to keep in mind the phenomenon of the hypothetical willingness to buy green products and to pay higher. Perception of green products is influenced to a large extent by market information and actions taken by the institutions that compose it, process and utilize the impact on consumers. In the Polish market there is an information gap and therefore untapped growth potential.

This study indicates that there is an interest of consumers buying green products, although consumers generally have only an elementary knowledge of issues related to the green production and labelling. One can notice the lack of discernment complexity and specific nature of the green products; they have no knowledge about the benefits of buying green products. They also have a sceptical attitude to the signs, questioning their credibility. It is necessary to remember that the bases of the market are the consumers who regularly buy green products. The most loyal group of consumers are consumers having health problems.

An analysis of the changes taking place in the Polish market for green products in the long term shows that the share of regular consumers is still small, but it is growing steadily. In recent years there can be seen the growing demand for green products. As indicated by various studies and analyses, this trend will continue over the next years. Despite the positive connotations associated with green products, the number of buyers is still low due to many reasons, among others, the lack of knowledge, low availability and low incomes. Consumers do not believe in the words of manufacturers and retailers. Also, the perception of the concept of green products is quite limited. Frequently, consumers associate them with green food. They have little awareness and the need to search for other products such as furniture, cosmetics, detergents, etc. Consumers also have very incomplete, fragmentary and general knowledge of their signs. A consumer is looking for safe products for health, made from natural ingredients, without pesticides, hormones, allergens, non-GMO and preservatives, food colourings and expects high quality products enriched with ingredients that have a positive impact on human health. In many cases, consumers have no choice; they are forced to buy such products, to ensure the proper functioning of them. Polish green market has a huge potential, which unfortunately is used only in a very small part, hence the urgent need to identify the barriers that limit its development. It should be noted that the development of the supply is conditioned by changes in the behaviour of consumers, who in their purchasing decisions include criteria related to environmental protection.
The current situation makes that green products require a proper marketing strategy, and particularly the role and scope of the use of the instruments of the marketing mix.

An attempt to clarify the gap is difficult as a lot of different individual, social and situational factors influence the decision-making process of consumers. Weigel (1983) suggests that the examination of personal and situational features would offer a more accurate insight into the relationship between attitudes and green shopping. Surveys receive an image of a socially desirable consumer, not the picture of their real behaviour. Understanding the discrepancy between attitudes and consumer behaviour in the market for environmentally friendly products requires longer approaches to research and the triangulation of research methods to understand the contexts of consumption. The Theory of Reasoned Action, the Theory of Planned Behaviour, Cognitive Dissonance Theory, Reciprocal Deterministic Theory and the Theory of Trying may be helpful in the explanation of the green attitudebehaviour gap. These issues should be considered in future studies.

Ecologically conscious consumers do not always make green purchases, which in turn makes it difficult for companies to implement green marketing strategies. It is necessary to examine how environmental attitudes affect consumers' behaviour towards green products and what is the importance of price and availability of these products and social influences, trust for green claims.

\section{References}

BARBER, N.A. - BISHOP, M. - GRUEN, T. 2014. Who pays more (or less) for proenvironmental consumer goods? Using the auction method to assess actual willingness-to-pay. In Journal of Environmental Psychology, 2014, no. 40, pp. $218-227$.

BARTELS, J. - HOOGENDAM, K. 2011. The role of social identity and attitudes toward sustainability brands in buying behaviours for organic products. In Journal of Brand Management, vol. 18, 2011, no. 9, pp.697-708.

BEZAWADA, R. - PAUWELS, K. 2013. What Is Special About Marketing Organic Products? How Organic Assortment, Price, and Promotions Drive Retailer Performance. In Journal of Marketing, vol. 77, 2013, no. 1, pp.31-51.

BRAGA JUNIOR, S.S. - SATOLO, E.G. - da SILVA, M.L.D. - da SILVA, G.D. 2014. The Relationship between Environmental Concern and Declared Retail Purchase of Green Products. In International Journal of Business and Social Science, vol. 5, 2014, no. 2, pp. 25-35.

BRAY, J. - JOHNS, N. - KILBURN, D. 2011. An exploratory study into the factors impeding ethical consumption. In Journal of Business Ethics, vol. 98, 2011, no. 4, pp. 597-608.

BUDER, F. - FELDMANN, C. - HAMM, U. 2014. Why regular buyers of organic food still buy many conventional products - product specific purchase barriers for organic food consumers. In British Food Journal, vol. 116, 2014, pp. 390-404.

CARRINGTON, M. - NEVILLE, B. - WHITWELL, G. 2010. Why Ethical Consumers Don't Walk Their Talk: Towards a Framework for Understanding the GAP between the Ethical Purchase Intentions and Actual Buying Behaviour of Ethical Minded Consumer. In Journal of Business Ethics, vol. 97, 2010, pp. 139-158.

CHEN, Y-S. - CHANG, Ch-H. 2012. Enhance green purchase intentions: The roles of green perceived value, green perceived risk, and green trust. In Management Decision, vol. 50, 2012, no. 3, pp. 502-520.

EDEN, S. - BEAR, C. - WALKER, G. 2008. Understanding and (dis)trusting food assurance schemes: consumer confidence and the 'knowledge fix. In Journal of Rural Studies, 2008, no. 24, pp.1-14.

EUROPEAN PARLIAMENT. 2015. http://www.europarl.europa.eu/RegData/etudes/ BRIE/2015/557009/EPRS BRI\%282015\%29557009 EN.pdf (11.10.2018).

EUROPEAN COMMISSION. 2009. Study on the Competitiveness of EU Eco-industry. Bruksela : ECORYS SCS Group.

FOLLOWS, S.B. - JOBBER, D. 2000. Environmentally responsible purchase behaviour: a test of a consumer model. In European Journal of Marketing, vol. 34, 2000, no. 5/6, pp. 723-746.

FURA, B. 2017. Modelling the ISO 14001 environmental management system diffusion with the use of logistic regression. In Jedlička, P. - Marešová, P. - Soukal, I. Doubleblind peer-reviewed: proceedings of the international scientific conference Hradec 
Economic Days 2017, Hradec Králové : University of Hradec Králové, 2017, Jan $31^{\text {st }}$ and Feb $1^{\text {st }}$, pp. 213-219.

GERRARD, C. - JANSSEN, M. - SMITH, L. - HAMM, U. - PADEL, S. 2013. UK consumer reactions to green certification logos. In British Food Journal, vol. 115, 2013, no. 5, pp. 727-742.

GLEIM, M. - LAWSON, S. J. 2014. Spanning the gap: an examination of the factors leading to the green gap. In Journal of Consumer Marketing, vol. 31, 2014, no. 6/7, pp. 503514.

GLEIM, M.R. - SMITH, J.S. - ANDREWS, D. - CRONIN, Jr J.J. 2013. Against the green: A multi-method examination of the barriers to green consumption. In Journal of Retailing, vol. 89, 2013, no. 1, pp.44-61.

GUPTA, S. - OGDEN, D.T. 2009. To buy or not to buy? A social dilemma perspective on green buying. In Journal of Consumer Marketing, vol. 26, 2009, no. 6, pp. 376-391.

GUTKOWSKA, K. 2007. Zachowania konsumentów w kontekście teorii konfliktu niewspółmiernych skal wartości. In Kędzior, Z. (ed.). Konsument. Gospodarstwo domowe. Rynek. Katowice : Akademia Ekonomiczna im. Karola Adamieckiego w Katowicach, Centrum Badań i Ekspertyz, 2007, pp. 78-101.

HARBAUGH, R. - MAXWELL, J.W. - ROUSSILLON, B. 2011. Label confusion: The Groucho effect of uncertain standards. In Management Science, vol. 57, 2011, no. 9, pp. 1512-1527.

HARTMAN GROUP. 2008. The many faces of organic 2008. Bellevue. WA. http:// academicsreview.org/wp-content/uploads/2014/04/Academics-Review OrganicMarketing-Report1.pdf (05.10.2018).

HAWS, K.L. - WINTERICH, K.P. - NAYLOR, R.W. 2014. Seeing the world through GREENtinted glasses: Green consumption values and responses to environmentally friendly products. In Journal of Consumer Psychology, vol. 24, 2014, no. 3, pp. 336-354.

HOSTA, M. - ŽABKAR, V. 2016.Consumer Sustainability and Responsibility: Beyond Green and Ethical Consumption. In Market-Tržište, vol. 28, 2016, no. 2, pp. 143-157.

HUGHNER, R. S. - MCDONAGH, P. - ANDREA, P. - SHULTZ, C.J. - STANTON, J. 2007. Who are organic food consumers? A compilation and review of why people purchase organic food. In Journal of Consumer Behaviour, vol. 6, 2007, no. 2-3, pp. 94-110.

JANSSEN, M. - HAMM, U. 2011. Consumer perception of different organic certification schemes in five European countries. In Organic Agriculture, vol. 1, 2011,no. 1, pp. 31-43.

JANSSEN, M. - HAMM, U. 2012. The Mandatory EU Logo for Green Food: Consumer Perceptions. In British Food Journal, vol. 114, 2012, pp. 335-352.

KAISER, F. - WOLFING, S. - FUHRER, U. 1999. Environmental attitude and ecological behaviour. In Journal of Environmental Psychology, vol. 19, 1999, pp. 1-19.

KOLLMUSS, A. - AGYEMAN, J. 2002. Mind the Gap: Why do people act environmentally and what are the barriers to pro-environmental behavior? In Environmental Education Research, vol. 8, 2002, no. 3, pp. 239-260.

KOLLMUSS, A. - AGYEMAN, J. 2002. Mind the gap: why do people act environmentally and what are the barriers to pro-environmental behaviour? In Environmental Education Research, vol. 8, 2002, no. 3, pp. 239-260.

KUMAR, B. 2012. Theory of Planned Behaviour Approach to Understand the Purchasing Behaviour for Environmentally Sustainable Products. In IIMA Working Papers, WP 2012-12-08, pp. 2-43.

KUŹNIAR, W. - WITEK, L. 2016. Traditional regional products as part of unique sales proposition on farm tourism in Poland. In Scientific Papers-Series Management Economic Engineering in Agriculture and Rural Development, vol. 16, 2016, no. 1, pp. 249-252.

LEWICKA-STRZAŁECKA, A. 2015. Mit konsumenta społecznie odpowiedzialnego. In Marketing i Rynek, 2015, no.10, pp. 3-9.

MOON, W. - FLORKOWSKI, W. - BRUCKNER, B. - SCHONHOF, I. 2002. Willingness to pay for environmental practices: Implications for eco-labeling. In Land Economics, vol. 75, 2002, no. 1, pp. 88-102.
MOSER, A.K. 2015. Thinking green, buying green? Drivers of pro-environmental purchasing behavior. In Journal of Consumer Marketing, vol. 32, 2015, no. 3, pp. 167-175.

NESTOROWICZ, R. 2017. Asymetria wiedzy a aktywność informacyjna konsumentów na rynku produktów żywnościowych. Poznań : Wyd. UEP, 2017.

ORBOI, M.D. - BĂNEŞ, A. - MONEA, M. - MONEA, A. 2012. Aspects regarding the organic food market. Agricultural Management Seria I. In Management Agricol, vol. 14, 2012, no. 2.

Pabian, A. 2014. Greenwashing i astroturfing. Zielona dezinformacja w działalności promocyjnej. In Marketing i Rynek, 4 (CD), 2014, pp.105-110.

ROKKA, J. - UUSITALO, L. 2008. Preference for green packaging in consumer product choices - Do consumer's care? In International Journal of Consumer Studies, vol. 32, 2008, no. 5, pp. 516-525.

ŚLIWAK, J. 2001. Osobowość altruistyczna. Osobowościowe korelaty altruizmu: psychologiczne badania empiryczne. Lublin : Redakcja Wydawnictw KUL, 2001.

STEG, L. - PERLAVICIUTE, G. - Van der WERFF, E. - LURVINK, J. 2014. The significance of hedonic values for environmentally - relevant attitudes, preferences and actions. In Environment and Behavior, vol. 46, 2014, no. 2, pp. 163-192.

TERENGGANA, C.A. - SUPIT, H. - UTAMI, C.W. 2013. Effect of Value, Consumer Trust and Attitudes towards Intention Buy Environmentally Friendly Air Conditioners Product in South Sumatera. In Academic Research Journal, vol. 4, 2013, no. 3, pp. 323-335.

THøGERSEN, J. 2009. Consumer decision - making with regard to organic food products. In Vaz, M.T.N. - Nijkamp, P. - Rastoin, J.L. (eds.), Traditional Food Production Facing Sustainability: A European Challenge. Farnham : Ashgate, 2009, pp. 173-194.

WEIGEL, R. H. 1983. Environmental Attitudes and the Prediction of Behavior. In Feimer N.R. - Geller E.S. (eds.). In Environmental Psychology: Directions and Perspectives, New York: Praeger, 1983, pp. 257-287.

WILLER, H. 2012. The European Market for Organic Food, Forschungsinstitut für biologischen Landbau. (FiBL) Frick : BioFach, 2012.

WITEK, L. 2016. Cause Related Marketing: the demographic-social qualities of consumers and their attitudes towards CRM. In Formankova, S. (ed.). Trends of Management in the Contemporary Society, $6^{\text {th }}$ International Conference on Management (ICoM), Brno, Czech Republic, Jun 09-10, 2016, pp. 205-208.

Witek, L. 2017. Barriers to green products purchase - from polish consumer perspective. In Dvoulety, 0. - Lukes, M. - Misar, J. (eds.). Innovation Management, Entrepreneurship and Sustainability (IMES 2017), Proceedings of the $5^{\text {th }}$ International Conference, Prague, Czech Republic : Univ. Econ, MAY 25-26, pp. 1119-1128.

YOUNG, W. - HWANG, K. - MCDONALD, S. - OATES, C.J. 2010. Sustainable Consumption: Green Consumer Behaviour when Purchasing Products. In Sustainable Development, vol. 2010, 18, pp. 20-31.

ZANNA, M.P. - FAZIO, R.H. 1982. The attitude-behavior relation: Moving toward a third generation of research. In Zanna, M.P. - Higgins, E.T. - Herman, C.P. (eds.). Consistency in social behavior, The Ontario symposium, Erlbaum Hillsdale, NY, vol. 2, 1982, pp. 283-302.

\section{Contact address}

Lucyna Witek, PhD, Rzeszow University of Technology, The Faculty of Management Department of Marketing ul. Powstańców Warszawy 8, 35-959 Rzeszów, Rzeszów, Poland, e-mail: Igarbacz@prz.edu.pl 